\title{
Education Classes and Wage Inequality among US Workers: 1950-2009
}

\author{
Richard R. Verdugo \\ National Education Association, Washington DC., UK. \\ Email: rverdugo@nea.org \\ Received May $18^{\text {th }}, 2011$; revised July $27^{\text {th }}, 2011$; accepted September $9^{\text {th }}, 2011$.
}

\begin{abstract}
A considerable amount of research consistently finds is that the better educated, generally, earn more than the less educated. It is also believed that better work and technical skills are linked to education. For these and other reasons, researchers and policy makers have long pushed for increasing the educational attainment of the American population. And, indeed, over the $20^{\text {th }}$ Century, the American population has become highly educated to the point where a high school education is no longer seen as a path to better economic status. Rather, a college degree has taken that role. Since about mid- $20^{\text {th }}$ century more Americans are going to college, and this may have important implications for income inequality? In this paper, I examine income inequality among four education classes (ECs): those with less than a High School Diploma, those with a High School Diploma, those with some college, and those with a college degree or more. I compute Gini Coefficients for all four groups for the years 1950 to 2009 using the Decennial Census and the 2009 American Community Survey. I also present a brief analysis about the contribution each EC makes to the overall Gini Index. My results point out that income inequality was initially driven by those with less than a high school education, was passed onto those with a high school diploma, and in recent years has greatly increased due to those with a college education. Moreover, I found that wage inequality was greater among the college educated than among the other ECs.
\end{abstract}

Keywords: Education classes, Gini Index, Wage Inequality

\section{Introduction}

There are always unintended consequences. A considerable amount of research points out that there are positive income returns to education. Research consistently finds that the better educated, in the aggregate, earn more than the less educated. Moreover, the prospects for the educated look good because, as the US economy has changed to a more knowledge-based economy, employers seek workers with technical and critical thinking skills. Consequently, researchers and policy makers have pushed for Americans to pursue higher levels of education. ${ }^{1}$

In the early decades of the $20^{\text {th }}$ Century, there were two primary motivations for acquiring more education: greater earnings that were flowing to the better educated, and a significant need for skilled workers. Both factors have been crucial in raising the educational attainment of the US population. And, indeed, over the $20^{\text {th }}$ Century, the American population has become so highly educated to the point where a high school education is no longer seen as a path to better economic status. Rather, that distinction now falls to a college degree.

Since about mid- $20^{\text {th }}$ Century, more Americans are graduating from high school and going to college. For example, by the 1970s about 75 percent of 17-year-old Americans had graduated from high school. In the early part of the $20^{\text {th }}$ century less than one-quarter had attained such status. Moreover, from the late 1970 s to the 1980 s, high school was no longer seen as the key to better jobs and greater pay; that role was increasingly taken on by college. In 1940, 4.6 percent of persons age 25 and over were enrolled in institutions of higher education. By 2009, the percent jumped to 29.5 percent (www.census.gov). One of the more overwhelming held views about education is that it would level the playing field and reduce income inequality.

${ }^{1}$ See Bell (1973).
But there has been important disconnect and unintended consequences. Despite the greater educational attainment of the US population, income inequality has also increased. In 1967, the Gini Index, as a measure of aggregate wage inequality, was .340 , and by 2008 it has increased to .403 (www.census. gov). Also, in 1947, the aggregate income share of the richest 5 percent in the US was 17.5 percent and by 2009 the share of aggregate income in the US held by the richest 5 percent was 21 percent (www.census.gov). By all available measures, then, income and wealth inequality in the US has increased. If education pays, then why this obvious disconnect? Shouldn't a trend of greater educational attainment reduce rather than increase income inequality? Why has the opposite occurred? Is education a contributor to wage inequality in the US? In this paper I examine average wages in four education classes, and then I use these findings to examine wage inequality among US workers from 1950 to 2009 . My basic research question is, "to what extent have education classes contributed to aggregate wage inequality among US workers?" Data for my study are from the 1950 to 2000 Decennial Census, and from the 2009 American Community Survey.

\section{Background}

\section{Education and Income Inequality}

The research on the relationship between education and earnings inequality draws three primary conclusions. First, some scholars find that the greater the average education in a society, the greater is the wage inequality (Becker, 1962, 1964; Checchi, 2000; Chenery \& Syrquin, 1975; Gregorio \& Lee, 2002; Marin \& Pasacharopoulous, 1976; Mincer, 1958a, 1958b, 1874; Schultz, 1961; Sylwester, 2002; Winegarden, 1979; Williamson, 1991). (However, Ram $(1984,1989)$ finds that no such effect exists.) 
A second body of research finds that the greater the level of schooling in a society (that is, a significant proportion with higher levels of schooling), the lower income inequality (Becker \& Chiswick, 1966; Checchi, 2000; Eicher \& GarciaPenalos, 2001; Gregorio \& Lee, 1999; Heshmati, 2004; Le Caillon, Paukert, Morrisson, \& Germidis, 1984; Mohan \& Sabot, 1988; Park 1996; Partridge, Partridge, \& Rickman, 1998; Tinbergen, 1975).

A third body of research finds that the relationship between education and income inequality is " $U$ " shaped. That is, inequality is a function of two factors: the movement out of agriculture and into manufacturing jobs, and the supply of educated labor (Bourguignon \& Morrisson, 1998; Fields, 1979; Knight, 1976; Kuznets, 1955; Motonishi, 2003; Papanek \& Kyn, 1986; Robinson, 1976). ${ }^{2}$ Basically, wage inequality is initially high as educated labor is paid a premium for such status, but declines as the supply of educated labor increases. It is an interesting conjecture that is related to the issue of surplus schooling (see Verdugo \& Verdugo, 1989)

While these findings seem ambiguous, on closer inspection they provide an important hint at several interesting and helpful social stratification explanations. A first hint concerns social structure. That is, the patterned and regular forms of social behavior that determine privilege and access. One scholar (Checchi, 2000) argues that the major reason this body of research fails to provide conclusive empirical results is because it cannot control for the evolution of social structures (social stratification being a form of social structure) in various countries, such as religion, ethnic composition, and culture. It is these forms of structured inequality that distribute privilege, access, and thus lead to economic inequality.

The difference between average schooling and level of schooling is a second reason for the seeming ambiguity. While average schooling is an important statistical concept, it is a static concept and cannot measure educational gradations, and the flow among such gradations, which is crucial for understanding how education access and privilege are distributed. Level of schooling does measure gradations of schooling and is capable of depicting the movements of people into various education niches, and thus access to a resource that distributes an important economic reward-wages. For example, change in the number and percent with a college degree versus those with a high school diploma can be used to gauge changes in the education classes and how wages are distributed among these classes. Average schooling simply cannot accomplish such a task.

A third stratification explanation is related to level of schooling and asks who is being educated, and if access to education, especially higher education, is limited by economics or by certain ascribed demographic factors, such as race, gender, religion, and social class. If only members from the upper social class or the children of the educated classes are able to attend college, for example, we can expect income inequality to continually be an important characteristic of a social system. In this paper I attempt to chart wage inequality among US workers by focusing on the role selected education classes take in the

\footnotetext{
${ }^{2}$ In fact, this particular question has a long history starting with the work by Adam Smith (see Griliches 1997).

${ }^{3}$ See Heilbroner, \& Singer (1994) for an excellent discussion of the economic transformation of the US. See particularly Chapters 6 through 17 .

4" When the Russians beat us into space, the public blamed the schools, not realizing that the only thing that had been proved was that their German scientists had gotten ahead of our German scientists." Lawrence A. Cre$\min$.
}

distribution of wages, and thus wage inequality.

\section{Education Income Inequality}

\section{Educational Attainment}

There have been three Great Educational Transformations in the United States (see Callahan, 1962; Cremin, 1980; Folger \& Nam, 1960). The first transformation occurred in the late $19^{\text {th }}$ Century and into the first decade or so of the $20^{\text {th }}$ Century when many young people were enrolled in primary schools. There appear to be two factors driving the primary school transformation: literacy and immigrants. During this phase in American history, decision makers believed it would be better for society if Americans were literate and better understood what it meant to be an American. As a literate population, Americans could read the Bible, keep up with politics, and follow instructions (see Bowles \& Gintis, 1976; Spring, 1973). In terms of immigrants, the perception was that primary school would not only socialize immigrants to the American Way of life, but would also teach immigrant youth English (Cuban, 2004; Tyack, 1974; Taggart, 1988).

The Secondary School Movement was the second transformation and it began in the first two decades of the $20^{\text {th }}$ century. The Secondary School Movement was driven by a growing industrial base, the need for skilled workers, and the push by prominent members of the American business community that wanted a vocational-based system much like that in Germany (Cuban, 2004; Callahan, 1962). ${ }^{3}$ There were other factors that also contributed to the push for establishing a secondary school system. Among these were free tuition and a standardized curriculum based on local values and interests. Previously, parents paid for their children to attend secondary schools, and free tuition opened schools to the masses. Also, an important aspect of this push for mass education was the development of a curriculum that prepared students for life, not just for college. The secondary school movement was diffusing across the country, vocational, and egalitarian.

The Third Transformation began about mid- $20^{\text {th }}$ Century with the push to have young people acquire a college education. The impetus behind the higher education movement was the changing industrial structure of the US, new technological developments, and the 1960 s space race. ${ }^{4}$ In fact, it was shortly after WWII with the returning GI cohort that the growth of higher education in America really took off-both in terms of enrollments and in the building of more institutions of higher education (see Jencks \& Reisman, 1969).

Of course, I have only briefly summarized these transformations. However, one can observe these transformations by looking at high school graduation and college enrollment rates. Figure 1 present's data on the high school graduation rate among 17 year old from 1869 to 2004 . The graph shows that high school graduation took off in the first two decades of the $20^{\text {th }}$ Century, and reached about 50 percent in the latter part of the 1930 s and early 1940 s. By the late 1960 s and early 1970 s, about 75 percent of 17-year-olds had graduated from high school, and this rate seems to have reached a plateau since then.

If secondary schooling was the second great educational transformation, higher education is the third. In 1940, about 6 percent of persons 25 years and over were enrolled in institutions of higher education. The percentage reached double digits around 1950, and grew monotonically until about the late 1970s. During the early part of the 1970s, there was a slight downturn, some flattening, and then an increase from about 1981. By 2009, over 30 percent of persons 25 and older were enrolled in institutions of higher education. (See Figure 2.) 


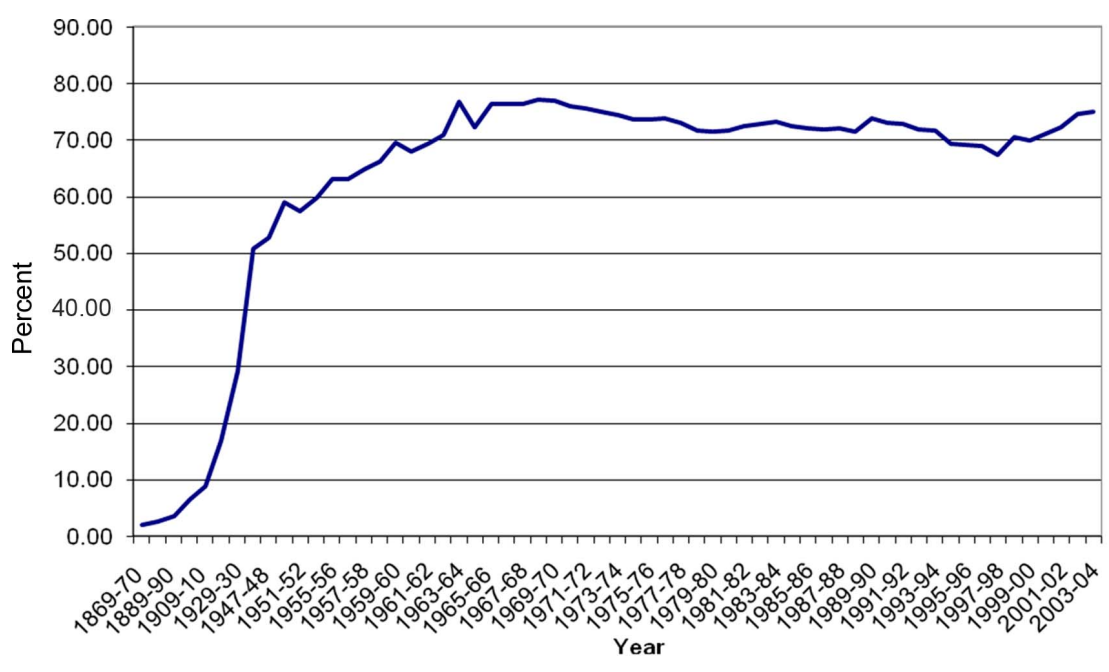

Figure 1.

17-Year Old High School Graduates as a Percentage of all 17-Year Olds, 1869 to 2004.

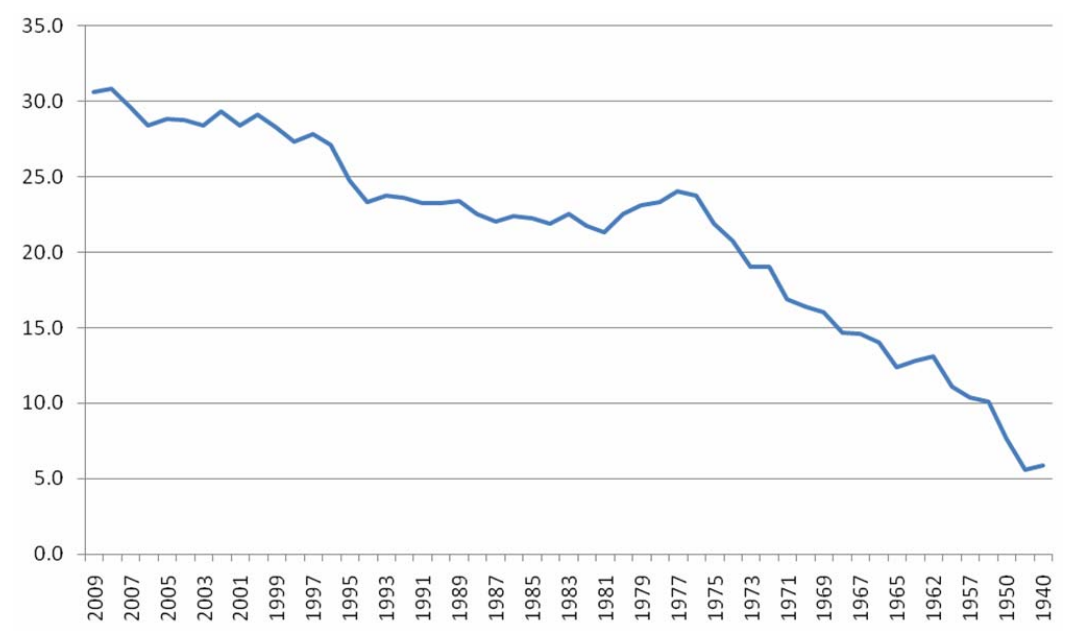

Figure 2.

Percent of 25 year olds and older enrolled in college: 1940 to 2009.

\section{Income Inequality}

Income inequality also has been an important trait of US society. ${ }^{5}$ On various measures, especially over the past 20 to 30 years, the economic advantage of the well-heeled has increased. Data in Figure 3 display the Gini Index of inequality for individual earnings for the years 1967 to 2008 . From about 1967 to roughly about 1969 there was a downturn in earnings inequality, but since then the Gini Index has risen sharply, so that by 2004, it was slightly over .400 .

Another way of charting the growing inequality in the US is by looking at the share of aggregate income held by the richest 5 percent in the US. These data are displayed in Figure 4.

In 1947, the top 5 percent richest people in the US held about 17.5 percent of aggregate income in the US. By 2009, the richest 5 percent in the US had garnered 20.7 percent of aggregate income in the US, or an increase of 18 percent. However, the share of aggregate income held by the richest 5 percent has not been continuously increasing. Between 1947 and 1986, the share of aggregate income held by the richest 5 percent de-

\footnotetext{
${ }^{5}$ See Phillips (2002).

${ }^{6}$ Data downloaded from the University of Minnesota's Population Research Center.
}

clined from 17.5 percent in 1947 to a low of 14.4 in 1981, and then it began to increase again until 1987 when it reached, more or less, its 1947 share (17.2 percent). The decline has been attributed to a decline in the stock market, a major source of income (in the form of dividends) for the wealthy. Never the less, these figures suggest that aggregate income inequality in the US is significant.

Both sets of data, increasing educational attainment and increasing income inequality, challenge a significant hypothesis held by many social scientists, that education levels the playing field and reduces inequality. However, as we have seen, the empirical data contradict such a view, and the though extant the literature on the education-inequality relationship is inconclusive, it offers, I believe, an important clue; education level might be important in determining aggregate income inequality.

\section{Methods}

\section{Data}

Data for my study are from two Census databases: the Decennial Census from 1950 to 2000, and from the 2009 American Community Survey. Table 1 lays out the descriptions for each data base. ${ }^{6}$ 
R. R. VERDUGO

167

Table 1.

Data bases used in this study.

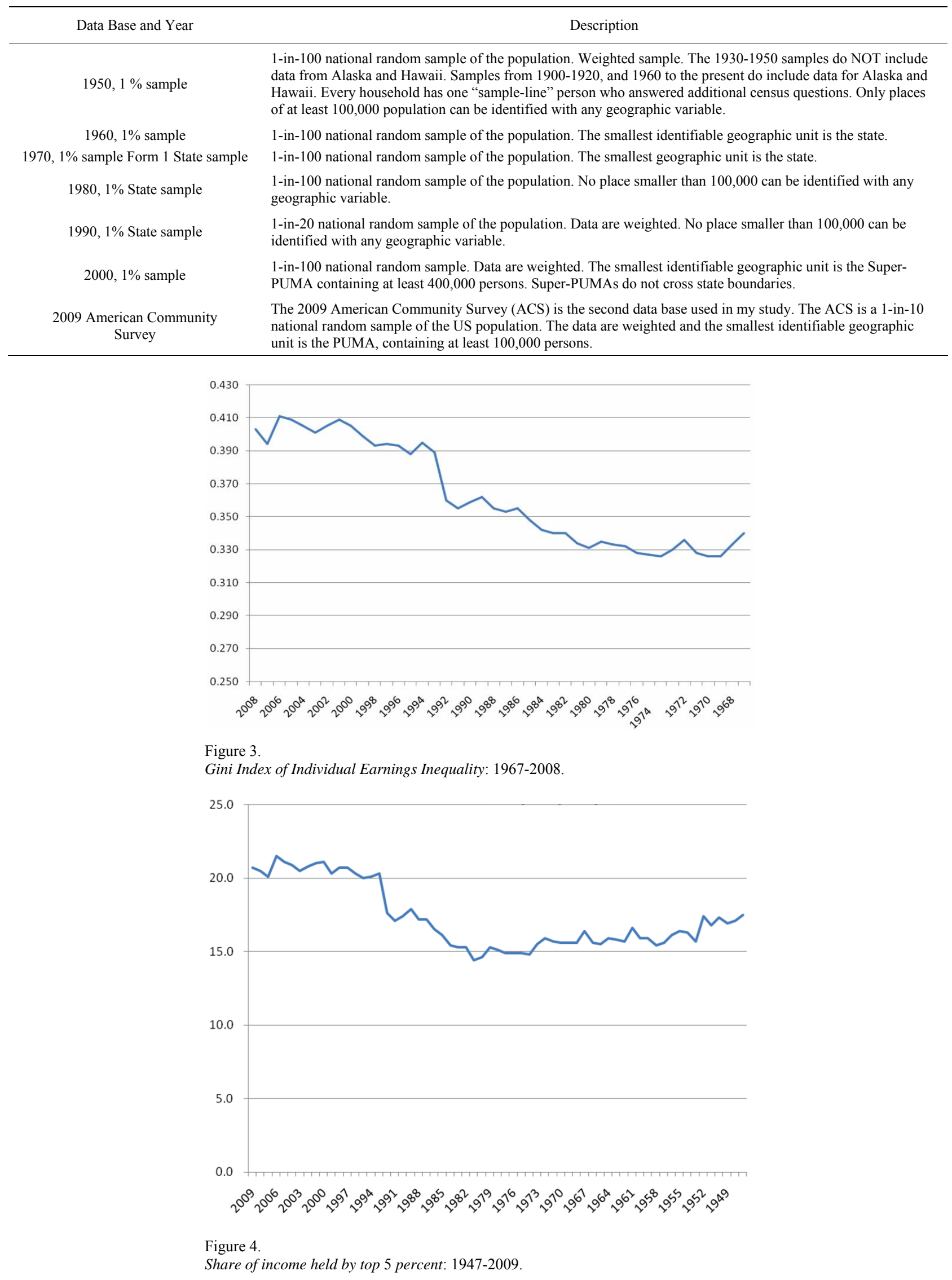


Data are limited to persons age 16 and older who were not in school, indicated that they were in the labor force, worked at least 40 weeks per year, and reported positive wages. ${ }^{7}$ Note that wages are in 2009 constant dollars.

\section{Variables}

\section{The Gini Index}

The Gini Index used in this study is:

$$
\mathrm{G}=1-\left\{\frac{[(2 / \delta) \times(\theta)+1]}{\mathrm{n}}\right\}
$$

where, $\delta=$ the maximum value of the cumulative income distribution, $\theta=$ the sum of the cumulative income distribution, minus the last value (the maximum value), $\mathrm{n}=$ total number of observations.

\section{Education Classes}

There are four education classes used in my study: Less than a high school education, high school education, some college, and college or more.

\section{Findings}

\section{Education Classes and Income: 1950 to 2009}

\section{Education Classes}

During the first half of the $20^{\text {th }}$ century, the education of the American population increased dramatically (for an excellent empirical demonstration see Folger \& Nam, 1960). The increase seems to have been driven by at least three factors. First, there was the expansion of free public education that was made available to everyone. A second factor was the mandates making school attendance mandatory for young people. The age at which a student could leave school varied by state: from 14 to 18. Moreover, by 1917, 30 states had passed such legislation. These 30 states had laws that made education compulsory to the age of 16. All but four of these 30 states allowed labor permits at or before the age of 14, and the remaining four states granted labor permits at age 15 . So, the effect of these compulsory laws seems to have been modest at best (Kessecker, 1929). A final factor was the changing US economy: a movement from agriculture to industry (see Heilbroner \& Singer, 1994). ${ }^{8}$

The educational attainment of the American working population increased greatly between 1950 and 2009. Of particular significance was the increase in the percentage of US workers with a college degree. Figure 5 displays the percent of the US labor force by education classes for the years 1950 to 2009 .

Note that the percent of US workers who are college educated has been increasing at a significant rate. In1950, the percent of the US labor force with a college education stood at 7.8

${ }^{7}$ There is an interesting pattern that occurs over the 1950 to 2009 period. Over this period, there is a significant decrease in the percent of the labor force age $65+$. These percentages are presented below:

$1950=4.86$

$1960=3.39$

$1970=3.23$

$1980=2.61$

$1990=2.67$

$2000=2.87$

$2009=3.98$

${ }^{8}$ The change in the US industrial system can be seen by the decline of the US labor force employed in agriculture. The data present the percent of the US labor force engaged in agricultural employment from 1900 to 2000. $1900=41 \% ; 1930=21.5 ; 1945=16 ; 1970=4 ; 2000=1.9$

Source: http://www.ers.usda.gov/publications/eib3/eib3.htm Anderton, Barrett, \& Bogue (1997) state that in 1860 fully 60 percent of the US labor force was employed in agriculture. The great transformation occurred about1880 (Anderton, Barrett, \& Bogue, 1997: p. 619). percent. By 2009, that percentage more than quadrupled to nearly one third $(32.8 \%)$ of the US labor force that was college educated, or an increase of 321 percent over that time span.

In direct contrast, the percent of the US labor force that had less than a high school education took a steep drop between 1950 and 2009. In 1950, over half of the US labor force (57 percent) had less than a high school education. By 2009, the percent plunged to 8 percent or a decline of over 600 percent. Thus, over the $20^{\text {th }}$ century and into the early part of the $21^{\text {st }}$ century, the US workforce has acquired more education.

The pattern for those with a high school education and those with some college experience also exhibited an increase, but less so than the other two education classes. Thus in 195027 percent of the US labor force had a high school education, and by 2009 it had increased to 35 percent. Among those with some college, the percentages were 8.6 percent in 1950 and 24 percent in 2009.

\section{Salaries \& Wages}

The average salary among US workers (all income data are in 2009 constant dollars) increased significantly between 1950 and 2009. Data are displayed in Figure 6.

The average wage among US workers increased between 1950 and 2009. In 1950, the average wage among US workers age $16+$ was $\$ 24,286$, and by 2009 it had increased to $\$ 49,704$.

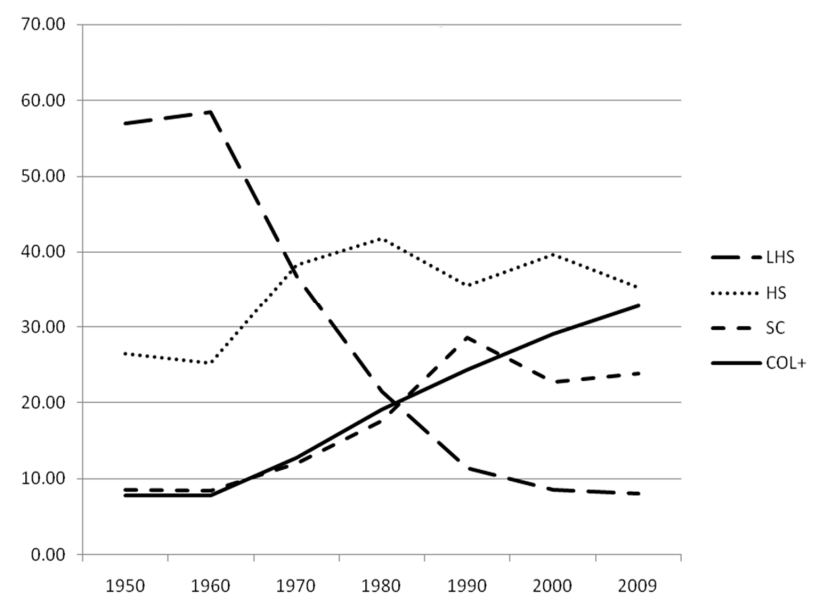

Figure 5.

Education of us works; 1950-2009.

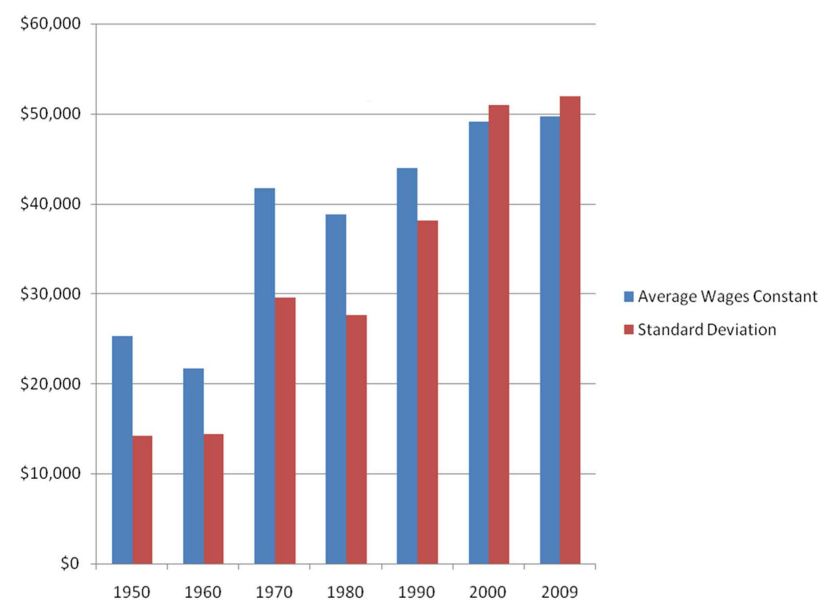

Figure 6 .

Aberage wages os US workers in constant 2009 dollars 1950-2009. 
In short, among US workers, average wages grew by 105 percent between 1950 and 2009. But also note a somewhat disturbing trend: wage dispersion also increased over this time period, suggesting growing wage inequality within the US labor force. This increase has been dramatic to the point where wage dispersion in 2000 and 2009 was greater than the average wage. In 1950 , wage dispersion was $\$ 14,215$ and by 2009 it had jumped to $\$ 51,906$, or an increase of 265 percent. Thus, among US workers, wage inequality increased between 1950 and 2009.

\section{Education and Wages}

While the wages of US workers increased significantly between 1950 and 2009, there are two pieces of information that point to increasing wage inequality. First, note that among all workers the dispersion, as represented by the standard deviation, also increased significantly over this time period. Indeed, by 2000 and 2009, the standard deviations for all workers were greater than the average salary, suggesting significant dispersion in salaries among US workers.

Second, I computed average wages by education classes and found that the average wages among the college educated grew at a greater rate than the less educated. These data are displayed in Figure 7.

The average wage of the college educated significantly grew between 1950 and 2009. In 1950, the average wage of the college educated was $\$ 35,000$, and by 2009 it had jumped to $\$ 76,326$, or an increase of 118 percent.

For the remaining education classes, the rise in average wages has been important but modest compared to the college educated. Table 2 displays changes in the average wages among the education classes between 1950 and 2009. Note the linear relationship between education and percent increase in wages.

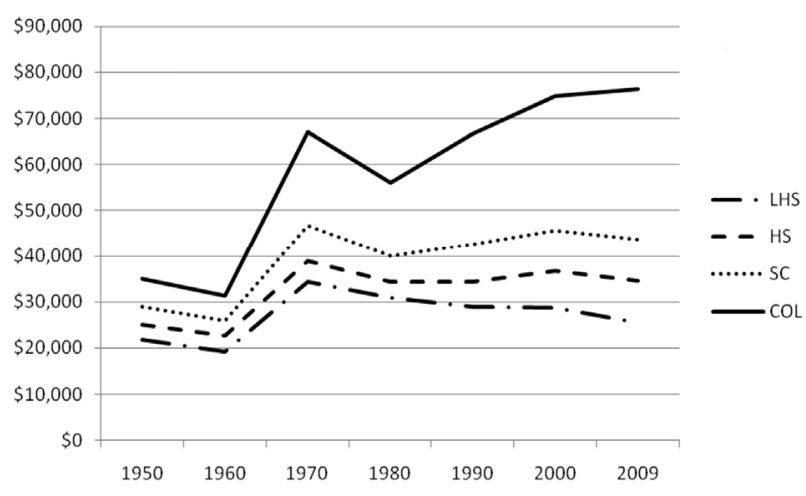

Figure 7.

Average wages of US workers by eduction classes in constant 2009 dollars: $1950-2009$.

Table 2.

Percent change in average wages among US workers: from 1950 to 2009.

\begin{tabular}{cc}
\hline Education Classes & Percent Change \\
\hline Less than High School & $17 \%$ \\
High School Graduate & $38.5 \%$ \\
Some College & $51 \%$ \\
College+ & $118 \%$ \\
\hline
\end{tabular}

There are at least two questions that come to mind in looking at these data. First, it seems to me that the rise in wage inequality is due to the larger share of wages being earned by the college educated, which may drive up total wage inequality. Second, I am curious as to which education class experiences the greatest wage inequality because this would also explain the overall increases.

\section{Wage Inequality among the Education Classes of US Workers: 1950 to 2009}

Figure 8 displays Gini coefficients for all US workers and for each education class. There are two stories being told in this chart. First, as expected, the overall level of wage inequality among US workers increased between 1950 and 2009. Between 1950 and 2009 the Gini grew from .321 to .452 . In short, as measured by the Gini coefficient, inequality grew by 41 percent between 1950 and 2009.

Second, wage inequality among the college educated exhibits the largest Gini Index among the educated classes. In fact, wage inequality was fairly significant among all education classes, but was particularly high among the college educated. In 1950, the Gini Index among college educated US workers was .346, and by 2009 it had grown to .424 , or an increase of $22.5 \%$. Between 1950 and 2009, wage inequality grew by 18 percent among those with less than a high school diploma; 31 percent among the high school educated; 14.6 percent among those with some college; and 22.5 percent among the college educated.

\section{Tinkering With the Gini Coefficient}

A question that we haven't resolved as of yet concerns the portions of the total Gini Index due to each of the education classes. Using our general Gini equation, we can provide an estimate to such a question. The Gini equation used in my study is,

$$
\mathrm{G}=1-\left\{\frac{[(2 / \delta) \times(\theta)+1]}{\mathrm{n}}\right\}
$$

and this is the Equation I will use in decomposing what proportion of the Gini is due to each of the education classes. The second half of the equation to the right of the equal sign is the area B in the graph below. That part of the Gini equation is inversely related to the final Gini Index.

So the greater the B, the smaller the Gini. In this section I provide estimates of the contribution each education class has to the Gini Index. Figure 9 displays the line of equality and the area of the Gini Coefficient.

The crucial portion of the Gini equation is Theta, $\theta$, which is simply the cumulative percentage distribution of wages, minus 100 , the last or maximum percentage. Within this cumulative distribution, there are parts due to those with less than a high school education, those with a high school diploma, those with some college, and those with a college education. So $\theta$ can be thought of as the sum of Theta: $\Sigma \theta_{i},(i=1, \cdots, 4)$. Hence, the percent of each class is simply $\theta_{\mathrm{i}} / \theta_{\text {., where }} \theta_{\mathrm{i}}=(1, \cdots, 4)$, and $\theta$. $=$ the total Theta.

The interpretation of these percentages is not completely straightforward. To begin with, they are nearly equal to the percent each EC has of total wages, so one plausible interpretation is that each Theta represents the percent an EC has of total wages, which would suggest that the greater the percent, the greater the inequality. Unfortunately, such is not completely the case. For example, in 1950 workers with less than a high school 


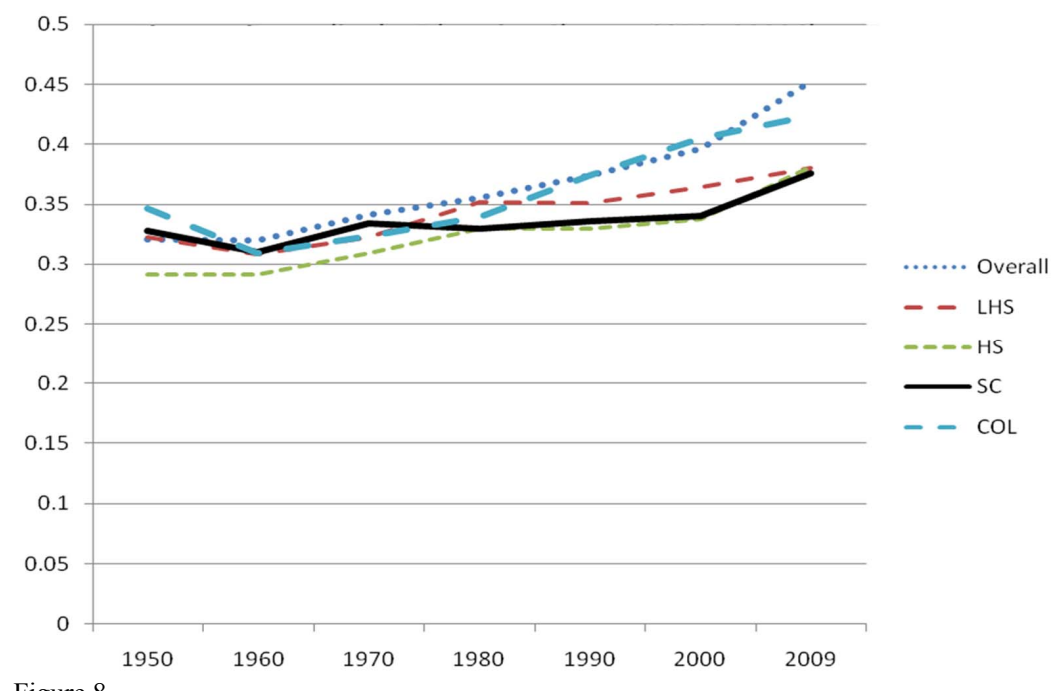

Figure 8.

Income inequality by Education Classes: 1950-2009.

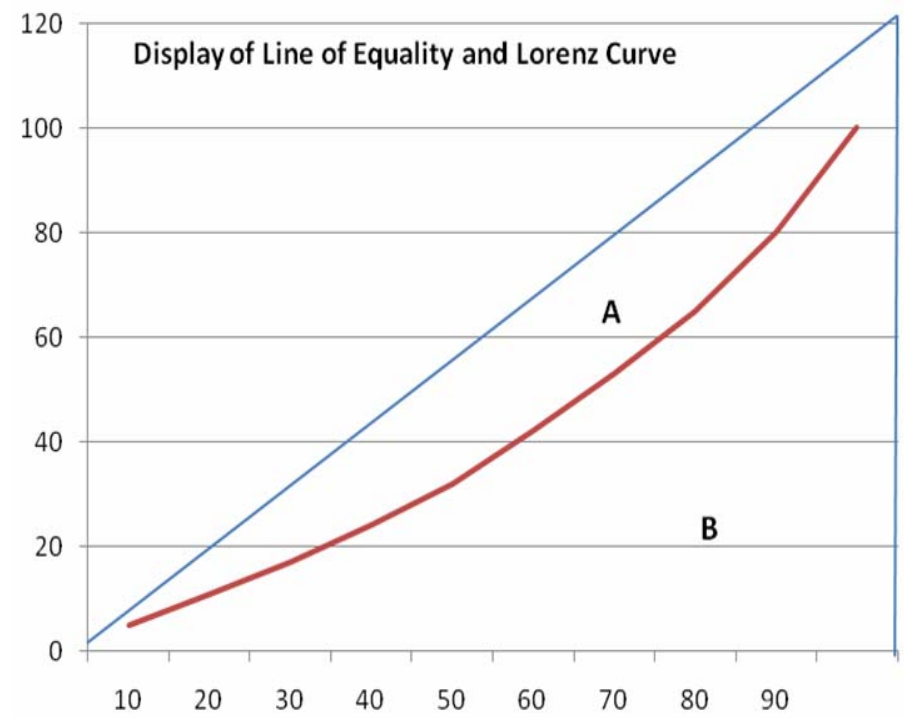

Figure 9.

Display of Line of Equality and the Area of the Gini Coefficient.

education had 51 percent of total wages, and yet the Gini Index for 1950 was lower than any other year thereafter. This brings up a second issue is that Theta must be interpreted along with the share of the total labor force held by an EC. In particular, inequality is related to a significant difference between an EC's Theta and Kappa, $\kappa$. Where Kappa is the percent of the total labor force held by an EC. For example, in 2009, the college educated held 50 percent of total wages, but were only 32.7 percent of the labor force. In 1950, while those with less than a high school education held 51 percent of wages, their Kappa percent was 48.7 percent. Data in Figure 10 display Thetas and Kappas for each EC for the years 1950 to 2009. Figure 10 is a stacked graph of both measures for each EC.

These graphs highlilght an interesting and yet expected trend. There are three stories being told in these graphs. To begin with, among workers with less than a high school education show significant declines in both their share of total wages and their share of labor. In 1950, as I pointed out, workers with less than a high school education had 51 percent of waegs and 48.7 percent of labor. But by 2009, their share plummeted to less than
10 percent for each. So where did these shares move to? If we look at those with a high school education, it appears that only a small share went to these workers. An examination of graph 9b reveals a fairly steady Theta and Kappa from 1950 to 2009.

In fact, graphs $9 \mathrm{c}$ and $9 \mathrm{~d}$ reveal that those with some college or with a college education realized significant increases in Theta and Kappa. Among those with some college, the growth in the combined Theta and Kappa between 1950 and 2009 was from about 20 percent in 1950 to about 50 percent in 2009 , or an increase of 150 percent. But the really significant growth is among the college educated. In 1950, the combined Theta and Kappa for the college educated was just under 20 percent. And by 2009 , it jumped to slightly over 80 percent, or an increase of about 300 percent. But this is only part of the story because while the college educated had about 50 percent of all wages, they represented less than one-third of the labor force. Thus, the increase in wage inequality among US workers from 1950 to 2009 can be attributed to a disproportionate share of wages going to the college educated. 


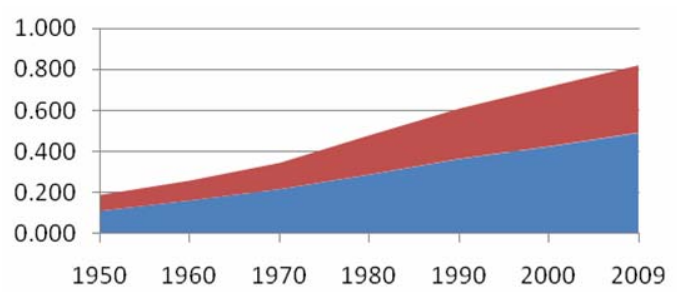

(a)

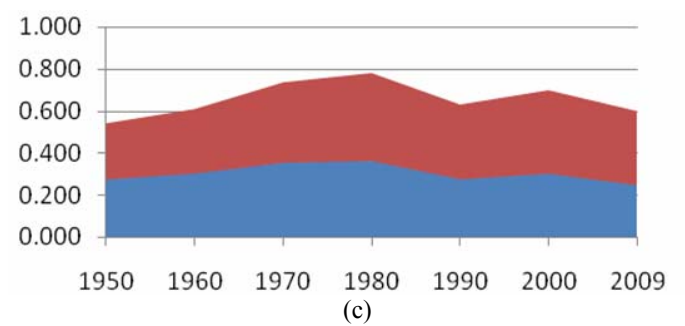

Figure 10 .

Kappa and Theta Rates by Education Classes: 1950-2009.

\section{Conclusion}

A well maintained set of beliefs among social scientists and the American public is not only that education pays in terms of wages and salary, but also that education reduces wage and income inequality. In other words, the education tide raises all ships.

A substantial body of research has looked into the relationship between education and wage inequality, and raises more questions than it has been able to answer. This body of work finds that greater average education is positively associated with wage inequality; that greater levels of schooling is negatively associated with wage inequality; and the greater the education inequality, the greater the wage inequality. What can one make of these seemingly and contradictory and scattered findings?

Such ambiguity, it seems to me can be explained by at least three factors: the level of a society's economic development or industrialization, the degree to which all economic classes have access to education, especially higher education, and inequality within education classes.

Wage inequality within education classes, unfortunately, has not received much examination by existing research. Such an analysis, it seems to me, would help us better understand the overall education-wage inequality pattern because it also would assist us in identifying where, within education classes, wage inequality is occurring. The primary purpose of my paper has been to examine the degree to which education has contributed to wage inequality among US workers. There are four primary findings from my research.

First, I found that while the education level of the US labor force grew significantly from 1950 to 2009 , the greatest increase has been among the college educated. Such an increase is in line with what some refer to as the Third Education Transformation in America.

Second, I not only found that the average wages of US workers increased between 1950 and 2009, but so did wage dispersion. In fact, by 2000 wage dispersion was greater than average wages, and the pattern continued into 2009. Such a finding suggested to me a significant amount of inequality from 2000 to 2009 . I then computed average wages for each educa-

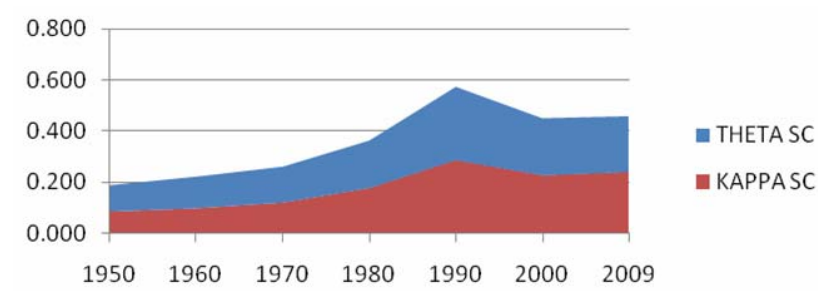

(b)

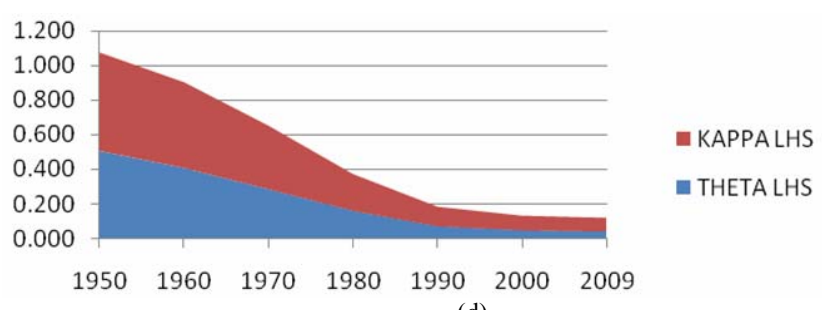

(d)

tion class and found that the greatest growth in average wages occurred among the college educated; an increase of $118 \%$ over the period 1950 to 2009, which was much greater than the other education classes.

Third, given these findings, I asked if wage inequality has also increased over time and if there were significant inequalities within each of the education classes. My analysis shows that, indeed, among the US work force age $16+$, wage inequality increased between 1950 and 2009. Moreover, the education class with the largest Gini Indices was the college educated.

Fourth, I tinkered with the Gini equation and was able to compute Thetas, which allowed me to compute the percentage of wage inequality due to each EC. These data, which must be tempered with the percent each EC has of the total labor force, or Kappa, indicate that as the movement of wages began to move up to the educated classes wage inequality increased.

There are two conclusions to be drawn from my research. First, it seems clear that if wage inequality has occurred among the US work force between 1950 and 2009, two major reasons are tied to the college educated class: they have realized significant gains in their wages, and there is significant wage inequality within their own ranks. In short, we might say that an important component of the increase in wage inequality among the US workforce can be attributed to supply of labor among the college educated class: their gaining a greater share of the total wages, and yet being a smaller shore of the labor force, greater wage inequality within their own ranks.

A second conclusion is driven by the increase in the ranks of the college educated class, their greater share of wages, and the increasing costs of acquiring a college education. In fact, researchers and policy makers have pointed out that the cost of attending higher education has become prohibitively expensive and is a barrier to the less well-heeled. If these patterns continue we may be witnessing the shaping of sharp class divisions in the US, and the continuing growth of wage inequality.

\section{References}

Anderton, D. L., Barrett, R. E., \& Bogue, D. J. (1997). The population of the United States. New York, NY: The Free Press.

Becker, G. S. (1962). Investment in human capital: A theoretical analysis. Journal of Political Economy, 70, 9-29. doi:10.1086/258724 
Becker, G. S. (1964). Human capital. New York, NY: Columbia University Press.

Becker, G. S., \& Chiswick, B. R. (1966). Education and the distribution of earnings. American Economic Review, 56, 358-369.

Bell, D. (1973). The coming of post industrial society. New York, NY: Harper.

Bourguignon, F., \& Morrisson, C. (1998). Inequality and development: The role of dualism. Journal of Development Economics, 57, 233257.doi:10.1016/S0304-3878(98)00089-3

Bowles, S., \& Gintis, H. (1976). Schooling in capitalist America: Educational reform and the contradictions of economic life. New York, NY: Basic Books.

Callhan, R. (1962). Education and the cult of efficiency. Chicago, ILL: University of Chicago Press.

Checchi, D. (2000). Does educational achievement help to explain income inequality? Working paper n. 11.2000. University of Milan, Italy.

Chenery, H. B., \& Syrquin, M. (1975). Patterns of development, 19501970. Oxford University Press for the World Bank.

Collins, R. (1979). The credential society. New York, NY: Academic Press.

Cremin, L. (1980). American education: The national experience 1783-1876. New York: Harper \& Row.

Cuban, L. (2004). The blackboard and the bottom line: Why schools can't be businesses. Cambridge, MA: Harvard University Press.

Fields, G. (1979). A welfare economic approach to growth and distribution in the dual economy. Oxford Journal of Economics, 93, 325353.

Eicher, T. S., \& Garcia-Penalosa, C. (2001). Inequality and growth: The dual role of human capital in development. Journal of Development Economics, 66, 173-197. doi:10.1016/S0304-3878(01)00160-2

Folger, J. K., \& Nam, C. B. (1960). The education of the American population. Washington, DC: US Department of Commerce.

Goldin, C. (1998). Egalitarianism and the returns to education during the Great Transformation of American education. New York, NY: National Bureau of Economic Research.

Goldin, C., \& Katz, L. F. (2008). Why the United States led in education: Lessons from secondary school expansion, 1910 to 1940. NBER Working Paper No. 6144.

Gregorio, J., \& Lee, J. W. (1999). Education and income distribution: New evidence from cross country data, Serie Economica 55, Universsidad de Chile.

De Gregorio, J. (2002). Education and income distribution: New evidence from cross country data. Review of Income and Wealth, 48, 395-416.

Griliches, Z. (1997). Education, human capital and growth: A personal perspective. Journal of Labor Economics, 15, S330-S344.

Jaspers, K. (1953). The origin and goal of history. London, England: Routledge and Keegan Paul.

Heilbroner, R., Singer, A. (1994). The economic transformation of america: 1600 to the present. New York, NY: Harcourt Brace College Publishers.

Heshmati, A. (2004). Inequalities and their measurement. Discussion paper series 1219, Institute for the Study of Labor, Bonn Germany.

Keesecker, W. W. (1929). Laws relating to compulsory education. Washington, DC: US Bureau of Education, G.P.O.

Knight, J. B. (1976). Explaining income distribution in less developed countries: A framework and an agenda. Oxford Bulletin of Economics and Statistics, 38, 161-177. doi:10.1111/j.1468-0084.1976.mp38003002.x

Kuznets, S. (1955). Economic growth and income inequality. American Economic Review, 45, 1-28.

Le Caillon, J., Paukert, F., Morrisson, C., \& Germidis, D. (1984). In- come distribution and economic development: An analytic survey. Geneva, Switzerland: International Labour Office.

Marin, A., \& Pasacharopoulos, G. (1976). Schooling and income distribution, Review of Economics and Statistics, 58, 332-338. doi: $10.2307 / 1924955$

Mincer, J. (1958a). Investment in human capital and personal income distribution. Journal of Political Economy, 66, 281-302. doi: $10.1086 / 258055$

Mincer, J. (1958b). On the job training: Costs, returns, and some implications. Journal of Political Economy, 70 , 50-79.

Mincer, J. A. (1974). Schooling, experience, and earnings. New York, NY: National Bureau of Economic Research.

Mohan, R., \& Sabot, R. H. (1988). Educational expansion and the inequality of pay: Columbia 1973-1978. Oxford Bulletin of Economics and Statistics, 50, 175-182.

doi:10.1111/j.1468-0084.1988.mp50002005.x

Motonishi, T. (2003). Why has income inequality in Thailand increased? An analysis using 1975-1998 surveys. Economics and Research Department, Working Paper Series No. 43, Asian Development Bank.

Papanek, G., \& Kyn, O. (1986). The effect on income distribution and development, the growth rate and economic strategy. Journal of Development Economics, 23, 55-65. doi:10.1016/0304-3878(86)90079-9

Park, K. H. (1996). Educational expansion and educational inequality on income distribution. Economics of Education Review, 15, 51-58. doi:10.1016/0272-7757(95)00000-3

Partridge, J. S., Partridge, M. D., Rickman, D. S. (1998). State patterns in family income inequality. Contemporary Economic Policy, 16, 277-294. doi:10.1111/j.1465-7287.1998.tb00519.x

Phillips, K. (2002). Wealth and democracy: A political history of the american rich. New York, NY: Broadway Books.

Ram, R. (1984). Population increase, economic growth, educational inequality, and income distribution: Some recent evidence. Journal of Development Economics, 14, 419-428. doi:10.1016/0304-3878(84)90069-5

Ram, R. (1989). Can educational expansion reduce income inequality in less developed countries? Economics of Education Review, 8, 185189. doi:10.1016/0272-7757(89)90006-X

Robinson, S. (1976). A note of the U hypothesis relating income inequality and economic development. American Economic Review, 66, 437-440.

Schultz, T. W. (1961). Investment in human capital. American Economic Review, 51, 1-17.

Spence, M. (1973). Job market signaling. Quarterly Journal of Economics, 87, 355-374. doi: $10.2307 / 1882010$

Spring, J. (1976). The sorting machine: National education policy since 1945. New York, NY: David McKay.

Sylvester, K. (2002). Can education expenditures reduce income inequality? Economics of Education Review, 21, 43-52. doi: $10.1016 / \mathrm{S} 0272-7757(00) 00038-8$

Tinbergen, J. (1975). Income distribution: Analysis and policies. Amsterdam, Netherlands: North-Holland.

Tyack, D. (1974). One best system. Cambridge, MA: Harvard University Press.

Verdugo, R. R., \& Verdugo, N. T. (1989). The impact of surplus schooling on earnings: some additional findings. Journal of Human Resources, 24, 629-643. doi:10.2307/145998

Winegarden, C. R. (1979). Schooling and income distribution: Evidence from international data. Econmica, 46, 83-87. doi: $10.2307 / 2553099$

Williamson, J. (1996). Inequality, poverty, and history. Cambridge, MA: Basil Blackwell. 